\title{
A ARTE COMO REPRODUÇÃO DE UMA VISÃO POLÍTICA POR "PINTO VEM AÍ” DE OLNEY SÃO PAULO
}

\author{
Taciane Barbosa dos Reis Lima e Cláudio Cledson Novaes \\ 1. Taciane Barbosa dos Reis Lima, PIBIC/CNPq, Graduando em Letras Vernáculas, Universidade Estadual de Feira \\ de Santana, e-mail: tacianareislima@outlook.com \\ 2. Cláudio Cledson Novaes, Departamento de Letras e Artes, Universidade Estadual de Feira de Santana, e-mail: \\ ccnovaes.orientacoes@gmail.com \\ 3. Participante do projeto : Imaginários Literários e Imagens Cinematográficas: Diversidade Cultural na Coletânea \\ BAHIA - 100 ANOS DE CINEMA, Departamento de Letras e Artes, Universidade Estadual de Feira de Santana
}

PALAVRAS-CHAVE: Política; Ditadura; Censura.

\section{INTRODUÇÃO}

Essa pesquisa teve como objetivo estudar um filme documentário de Olney São Paulo, para analisar algumas questões políticas da obra no contexto dos anos 1970. Para realizar a discussão foram identificadas referências bibliográficas sobre os temas envolvidos na obra, como, por exemplo, o cenário político local e nacional na época do Regime Militar após o golpe de 1964. Neste contexto está inserida a obra do cineasta jacuipense Olney São Paulo e o personagem principal do seu filme analisado, o político feirense Francisco José Pinto dos Santos. O período foi marcado pela repressão e a censura, principalmente depois da edição Ato Inconstitucional no 5 (AI-5), em 1968, para impedir manifestações que discordassem do regime.

Este é o cenário que Olney São Paulo marcou a obra literária e cinematográfica e a sua trajetória de vida. O menino nascido no interior da Bahia, mais precisamente na cidade de Riachão do Jacuípe, passou por Feira de Santana e chega ao Rio de Janeiro, como afirma José (1999, p.9), Olney tinha a postura do rebelde assumido, sem medo e sem ódio, mas com a firme determinação de opor-se a qualquer tipo de autoritarismo. Por meio de suas obras trazia o anseio pela liberdade, o que gerou grandes conturbações em sua vida, já que Olney ia de encontro ao que instituía o Regime Militar. Dentro os problemas vividos pelo Cineasta, houve o trágico desfecho após a produção do filme Manhã Cinzento (1969), quando foi preso por seu filme ser acusado de retratar uma imagem de denúncia ao sistema.

Outro elemento observado através desses estudos foi a autenticidade das produções cinematográficas de Olney São Paulo, já que o mesmo nunca dispôs de grandes ferramentas para as suas produções. Olney se encaixa perfeitamente ao que se chama de diretor-autor, como afirma Rocha (2003, p. 34-35), que recusa a "história", o "estúdio, a "estrela", os "refletores", os "milhões"; necessita apenas uma ideia na 
cabeça, uma câmera na mão, no mais, algumas películas e o indispensável para filmar em liberdade. Realiza filmes socialmente engajados e não se cala diante das mazelas sociais nem das realidades contraditórias.

Olney São Paulo traz essas movimentações em suas produções, como no documentário Pinto vem aí (1977), que retrata muito bem as denúncias feitas pelo Cineasta do cenário político pós-golpe de 64, o que reafirma a condição autoral do cineasta. O filme documentário Pinto vem aí (1977) marcou o retorno de Olney São Paulo a um tema político direto, após ser processado por produzir Manhã Cinzenta (1969). $O$ documentário retrata o retorno do exílio do Ex-Deputado, e prefeito exilado de Feira de Santana, Francisco José Pinto dos Santos, homem integrado ao denominados autênticos do Movimento Democrático Brasileiro (MDB).

Francisco Pinto foi um homem extremamente honesto, humilde e que sempre lutou contra o regime autoritário que se instalava na época, e assim como Olney São Paulo foi punido por causa de seu posicionamento. A volta de Francisco Pinto foi registrada pelo olhar sensível, inteligente e crítico de Olney São Paulo, e foi através desse olhar que o Cineasta registrou as imagens do retorno do político entre seus conterrâneos.

O posicionamento de Francisco Pinto pode ser observado em seu discurso perante a população de Feira de Santana, que durante uma coletiva de imprensa o político, além de relatar alguns processos pelos quais passou por conta de sua postura de oposição ao regime, denuncia o governo fascista que ainda permanecia no poder. Por meio de suas falas, Francisco Pinto provoca nos cidadãos reflexões acerca do Regime Militar, dando encorajamento ao povo a lutar por seus direitos e liberdade, por mais que a democracia estivesse negada. Olney São Paulo por detrás das câmeras repercutia esse discurso, fazendo também o seu discurso cinematográfico em prol da liberdade de expressão.

\section{MATERIAL E MÉTODOS OU METODOLOGIA (ou equivalente)}

Para a realização desses estudos foram utilizados artigos e coletânea de artigos científicos, além da exibição do filme, contando com o método qualitativo de pesquisa em referências bibliográficas e outros suportes.

\section{RESULTADOS E/OU DISCUSSÃO (ou Análise e discussão dos resultados)}


[...] O cinema condensa o curso das coisas, pois contém o antes que se prolonga no durante e no depois, significando a passagem, a tensão do próprio movimento representado em imagens dinâmicas, não mais capturadas num instante pontual, estático, como na fotografia (PELLEGRINI, 2003, p.18).

Partindo da concepção de cinema de Pellegrini, ao qual atribui a movimentação de e com imagens, pude perceber como Olney São Paulo, com uma simples câmera na mão pôde captar, através da sua leitura atenta do momento político brasileiro, a importância do retorno do exílio para a trajetória de vida de Francisco Pinto no filme Pinto vem aí (1977), mostrando como o cinema pode ser uma ferramenta de crítica e denúncia.

Olney São Paulo era um homem bastante sensível, inteligente, e destemido, pois através da pesquisa pude perceber que ele alimentou os planos de fazer cinema desde jovem, e já exprimia aquilo que viria ser mais tarde a inquietude do cineasta.

Foi possível analisar também toda a persistência de Olney São Paulo para produzir arte, enfrentando a repressão e falta de recursos, contribuindo para registros importantes da memória nacional, como é o caso do filme Pinto vem aí (1977).

Por fim, acho importante destacar a forte inter-relação de pensamentos, posicionamentos e posturas entre Olney Alberto São Paulo e Francisco José Pinto dos Santos, pois ambos eram seres que discutiam a sociedade, e mesmo com tantas perseguições jamais abandonaram a incansável luta pela liberdade do povo brasileiro.

\section{CONSIDERAÇÕES FINAIS (ou Conclusão)}

Estudar a vida do cineasta Olney São Paulo é algo de grande relevância, principalmente por conter em suas produções uma enorme sensibilidade e por ele conseguir trabalhar com temas tão emblemáticos e ter produções tão cheias de significado mesmo não obtendo grandes recursos.

Pinto vem aí (1977) teve enorme impacto sobre minha formação acadêmica, pois me fez conhecer uma época tão opressora que foi a Ditadura Militar e ver como Olney e Francisco Pinto lutaram contra ao fascismo em prol da democracia e da liberdade.

Seria extremamente significativo um maior aprofundamento em outros aspetos da produção Pinto Vem aí (1977) e na vida de Francisco Pinto como também um maior conhecimento acerca da trajetória de Olney e suas outras produções. 


\section{REFERÊNCIAS}

CHARLEAUX, João Paulo. Maio de 1968: as origens e os ecos dos movimentos. Disponível em:

<https://www.nexojornal.com.br/explicado/2018/05/05/Maio-de-1968-as-origens-e-osecos-do-movimento>. Acesso em: 08 junho 2018.

GUIMARÃES, Maria Beatriz; MARQUES, Ana Amélia. FRANCISCO JOSE PINTO DOS SANTOS. Disponível em: <http://www.fgv.br/cpdoc/acervo/dicionarios/verbetebiografico/francisco-jose-pinto-dos-santos>. Acesso em: 03 abr. 2018.

JOSÉ, Angela. Olney São Paulo e a Peleja do Cinema Sertanejo. Rio de Janeiro: Quartel Editora \& Comunicações Ltda, 1999.

NOVAES, Claudio Cledson. Aspectos Críticos da Listeratura e do Cinema na Obra de Olney São Paulo. Salvador: Quarteto Editora, 2011.

NOVAES. Claudio. D. CARNEIRO. Mírian.OLNEY SÃO PAULO: Breves Aspectos da Pesquisa Sobre o Percurso do Cineasta. Número temático: literatura e cinema. A Cor das Letras - UEFS, n. 11, 2010.

RIBEIRO, Denise Felipe. O regime civil-militar brasileiro e a questão do exílio.

Disponível em:

<http://www.encontro2012.rj.anpuh.org/resources/anais/15/1338518208_ARQUIVO_T rabalhoAnpuhRJ2012.pdf >. Acesso em: 6 de maio de 2018.

ROCHA, Glauber. Revisão Crítica do Cinema Brasileiro. São Paulo: Cosac \& Naify, 2003.

XAVIER, Ismail. Cinema Brasileiro Moderno. 3. ed. São Paulo: Editora Paz e Terra S/a, 2006. 